Portland State University

PDXScholar

\title{
Volunteering to Colonize: a Cost-Benefit Analysis of the Impacts of Voluntourism
}

Yetta Rose Stein

Portland State University

Follow this and additional works at: https://pdxscholar.library.pdx.edu/honorstheses

Let us know how access to this document benefits you.

\section{Recommended Citation}

Stein, Yetta Rose, "Volunteering to Colonize: a Cost-Benefit Analysis of the Impacts of Voluntourism" (2017). University Honors Theses. Paper 411.

https://doi.org/10.15760/honors.410

This Thesis is brought to you for free and open access. It has been accepted for inclusion in University Honors Theses by an authorized administrator of PDXScholar. Please contact us if we can make this document more accessible: pdxscholar@pdx.edu. 
Volunteering to Colonize:

A Cost-Benefit Analysis of the Impacts of Voluntourism

\author{
by \\ Yetta Rose Stein
}

An undergraduate honors thesis submitted in partial fulfillment of the requirements for the degree of

Bachelor of Arts

in

University Honors

and

International Studies

Thesis Adviser

Professor Stephen Frenkel

Portland State University 


\section{TABLE OF CONTENTS}

Introduction 4

Defining voluntourism and neocolonialism

Motivations

Voluntourist . .10

Voluntourism Organization .....................................................................................12

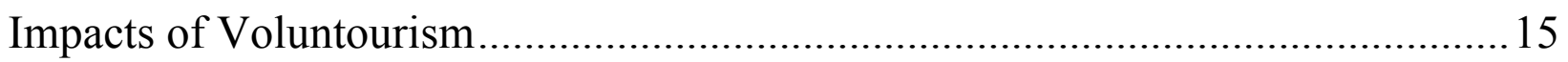

\section{Positives}

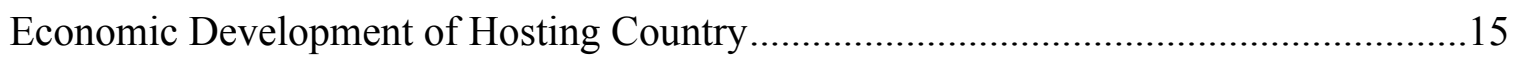

Increased Global Awareness and Engagement ……………........................................16

\section{Negatives}

Advancement of Neocolonial Relationships............................................................20

Lasting Economic Development and Aid Reliance ......................................................24

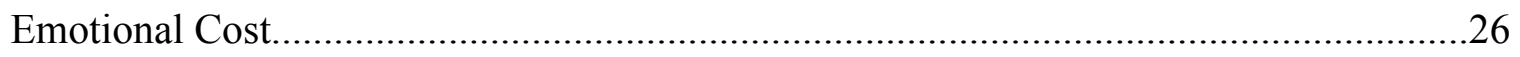

Environmental Resource Management .....................................................................28

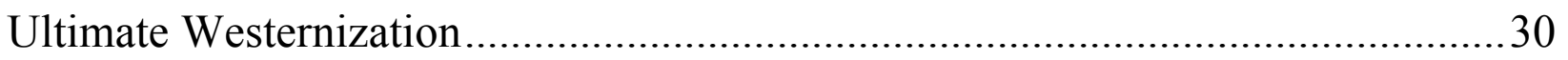

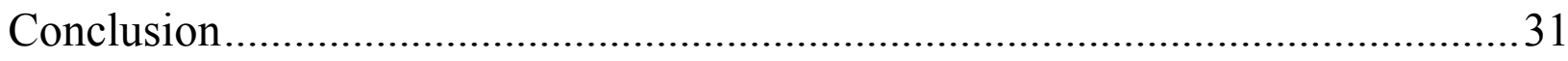

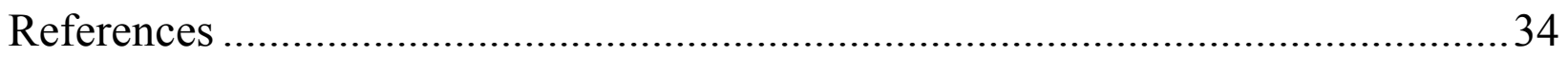


"Service to others is the rent you pay for your room here on Earth"

-Muhammad Ali

"The native must realize that realize that colonialism never gives anything away for nothing"

-Frantz Fanon 


\begin{abstract}
This paper examines the positive and negative implications of voluntourism, defined as a short-term trip (less than three months) of paid travel combining the vacation aspects with volunteer work externally organized. This paper compares the motivations of both the voluntourist and the voluntourism organizations. Ultimately, this paper seeks to ask: is voluntourism more negative or more positive? This paper compiles past ethnographic literature within the tourism and voluntourism community. This paper finds that voluntourism is neocolonial in nature, creates economic relationships built on aid reliance, does not help to form long-lasting social relationships and is irresponsible in its management of resources. Because of these factors, voluntourism, while not necessarily malicious in intent, is more negative than positive and will require a large framework shift to change its imperialistic legacy.
\end{abstract}

\title{
INTRO
}

As the world becomes more globalized and active, travel becomes easier and international interaction beyond borders becomes the norm. While some tourists spend their days lying on beaches, hiking in mountains or on cruise ships abound, a growing industry has emerged: tourists who spend their vacation time volunteering. This practice has come to be referred to as voluntourism

The industry and act of voluntourism, though widely accepted as beginning in 1915 (Gillette. 1968; Beigbeder 1991), really took off in the main stream sector with the creation of the Peace Corps by President John Kennedy in 1961 (Verardi 2013). The Peace Corps was a mission set forth by President Kennedy during the heart of the Cold War. Totted with a public service mission, the Peace Corps self-proclaimed "a bold new experiment" for US citizens abroad (“The Founding Moment” 2017). The Peace Corps became a 'gate-way' into the world beyond US borders. The Peace Corps also began the conversation surrounding the sometimes-problematic desire to 'help'. Peace Corps was the first organized combination of volunteer work and travel abroad. It's creation held to 
develop a path for many organizations to market this combined experience. Though the Peace Corps work is far beyond today's understanding of short-term volunteer tourism trips and outside the scope of this paper's definition of voluntourism, it's important to understanding the original intent and inception of voluntourism.

Since the advent of the Peace Corps, the voluntourism industry has grown. Voluntourist trip planners and organizations have expanded and broadened their country destinations, ranging across six continents; length of time spent in a country has increased and decreased; and the draw of applicants has expanded far past those interested in career foreign service or nomadic hippies. Voluntourism has "left behind the niche market" and "attained a place within the mainstream travel industry" (Patel 2013). It's popularity is not only reflected by the astonishing amount of voluntourism organizations (Figure 1), but also seen through reporting and informational articles surfacing in the main-stream media: Shivani Vora's “How to Plan a Volunteering Location” (New York Times, 2017), Ossob Mohamud's “Beware the 'voluntourists’ Doing Good” (The Guardian, 2013), Carrie Khan's “As Voluntourism Explodes in Popularity, Who’s It Helping Most?” (NPR, 2014), and Pippa Biddle's “The Problem With Little White Girls, Boys and Voluntourism" (Huffington Post, 2014). All of these articles ask the motivations and purpose of an international tourist trip based solely in volunteer work.

Voluntourism is here to stay, at least for the foreseeable future. Research surrounding voluntourism focuses on the motivations and implications of voluntouring practices, most often examining the effectiveness of physical projects. Sometimes examined are the societal perceptions of the voluntourist. All of these factors will be expanded on in last sections. In order to properly discuss the country participating in the 
voluntourism and the country receiving the voluntourism, this paper will term the country seeking to provide the help as the 'delivering country' and the country being traveled to and voluntoured in as the 'receiving country'.

I chose to study voluntourism because I, myself, have been a voluntourist. My first year of university, I traveled with 10 other students to Matagalpa, Nicaragua, to help build a school. Our organization was not religiously affiliated but rather was seeking to help a rural and indigenous community, after a community applied for this sort of aid. When I returned from my trip, I felt a sense of fulfillment and a desire to travel more. I wanted to talk about my experiences and live a more 'Nicaraguan' lifestyle. Little did I know I was romanticizing poverty and turning a chance to educate myself about privilege into resume enhancing social media post.

Beginning this research process, through analyzing the motivations for voluntouring, I was forced to ask myself the same question: why did I choose to voluntour? The answer was simply and humbling: I wanted to see a different part of the world and I wanted to have some sort of volunteer experience to put on my resume; I wanted to help and I wanted to be seen helping. These reasons directly correlate, as we will see, with the data I complied tracking voluntourist motivations. The more I read and understood about the skewed motivations of voluntourism, the more I had to look in the mirror and ask myself: was I volunteering to colonize? What are the long-term implications of voluntourism? And even, did the school I worked on ever get built in totality and is it being used for that purpose today?

In this paper, I begin by examining the motivations of both the voluntourist and the voluntourism organization. There is a wide and critical gap between the goals of the 
two codependent groups. This gap leads me to analyze the implications of voluntourism, both negative and positive. Rather than examining one specific country, I draw from studies conducted all over the world, showing that while voluntourism is different in physical practice and location, it's outcomes are generally the same. The patterns and tendencies of voluntourism are clear, from both the standpoint of the receiving country and the delivering country: the negative cost of voluntourism outweighs the possible benefits of its practice.

\section{DEFINING VOLUNTOURISM}

The growing popularity of merging volunteering and tourism, usually while traveling abroad from ones home country, calls for the defining of such a practice. In this paper, voluntourism will be defined as the a short-term trip, that is, less than three months, spent outside a person's home country while participating and paying for an externally organized volunteer project. The potential projects, for example could include building schools, working in hospitals or teaching English to the local population. This definition is derived from the expanding discourse community of voluntourism and purposefully excludes long-term voluntourism-esc projects like Peace Corps (Daldeniz and Hampton, 2010, Wearing 2001, McLennan 2014, Dykhuis 2010).

In his book 'Volunteer Tourism' (2001), Stephen Wearing defines 'volunteer tourism' for the first time and argues that voluntourism, when best executed, offers a better alternative to tourism than the standard capitalist and profit-based tourism (i.e. vacationing). His book presents voluntourism as a necessity in "providing forms of community development that are required by local communities" (Wearing 2001). Voluntourism, Wearing (2001) states, in beneficial because its an exchange of ideas. 
While Wearing presents a critical lens of voluntourism through the experiences of the "Volunteer Experience" and surmises "volunteer tourists... make a difference not only in the places they interact with, but also within themselves", this paper will address if the positive voluntourist experience is worth the cost and implications for the country being voluntoured in. I ask: are the negative impacts of voluntourism outweighed by the positive impacts it has the potential to create? This paper seeks to challenge the assertion made by Wearing (2001), who argues that voluntourism is needed for its development impacts and its support of human interaction. By studying the motivations and implications voluntourism, we can decipher whether the standard voluntourist practices are facilitating a neocolonial relationship between two countries part of the exchange. This paper is a literature review and compilation of the previous ethnographic studies completed by the tourism and voluntourism discourse community tracking the motivations of the voluntourist as well as the positive and negative impacts of voluntourism.

The goal is not to present an in-depth examination of one country in particular. Rather, to view voluntourism from a large scope in many different countries, pointing to the large themes and practices of the industry. The several countries used as case study in this paper, the same motivations of voluntourists and the same impacts- both negative and positive- occur and patterns voluntourism commonplace practices emerge.

I will begin by examining the array of motivations for those who participant in voluntourist trips and the stated motivations of the organizations providing the voluntourism experience. Then, using case-study country specific research from multiple places to outline the potential positive and negative impacts of voluntourism all over the 
world. I will conclude by presenting voluntourism as more negative than positive in current practice. 


\section{MOTIVATIONS OF VOLUNTOURISTS ${ }^{1}$}

Before examining the impacts of voluntourism through both a negative and positive lens, it is important to first address the motivations of voluntourists and voluntourism organizations. The voluntourism sector continues to grow and adapt, not necessarily to the needs of the receiving country, but rather, to make voluntourism a more profitable and fruitful market.

The image to the right shows the relatively small size of the profitability and popularity of the voluntourism sector. However, it is truly astonishing how quickly the voluntourism industry has grown: the short-term voluntourist trip didn't really emerge until the GLOBAL WELLNESS INSTITUTE

\section{Global Tourism Industry}

\$3.2 trillion

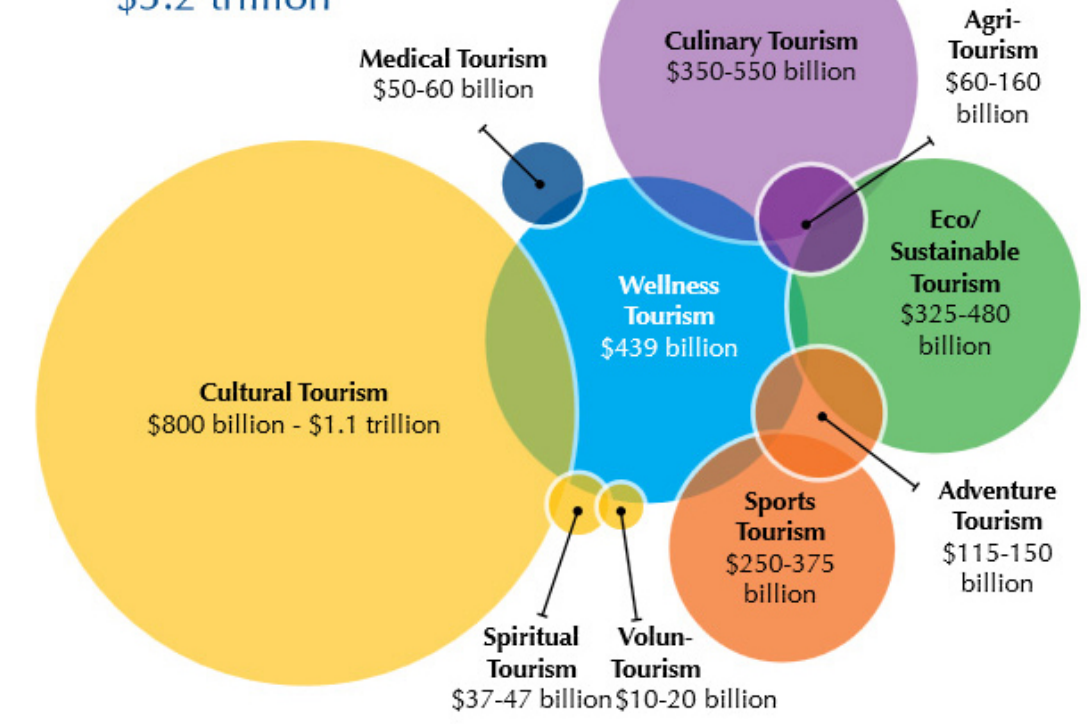

(c) Global Wellness Institute. Originally published in "The Global Wellness Tourism Economy," 2013

Corporate Social Responsibility Initiatives in the 1990's and were generally sold as an option for a guilt free holiday (volunteertourismviews 2013). Voluntourism trends, then, began to mirror the rise of tourism trends but on a smaller scale.

Daldeniz and Hampton (2010) integrate three studies previously completed in Malaysia, terming specifically the practice of "lifestyle voluntourism". Researching to

\footnotetext{
${ }^{1}$ Photo courtesy of the Global Wellness Institute ("Statistics \& Facts" 2017)

${ }^{2}$ Altruism tourists

${ }^{3}$ Photo courtesy of Travelocity's 'Travel for the Good' Campaign launch
} 
uncover the underlying reasoning behind why individuals (usually young students or post-graduates) move or travel from their home country to live in abroad in a 'developing' country, the authors compare these individuals to those who move abroad to work or volunteer in the tourism industry, specifically studying Malaysia and the diving industry. The authors found that these voluntourists are more often motivated by a desire for the voluntourist to fill their $\mathrm{CV}$ or in the hopes to create a general feeling of selfenhancement (Daldeniz and Hampton 2010).

Wearing (2001) tends to agree with this analysis. He states generally that while some voluntourists were motivated by past experiences, like volunteer work, most were interested in working in a volunteer or non-profit field and considered their time as a voluntourist as professional development. Some volunteers were excited about the "adventure" of traveling abroad; still some found that their opportunity was simply "right time-right place" (Wearing 2001). The "adventure" motivation to voluntour is supported by Sichel (2006), who states that "'Altourists, ${ }^{2}$, or development tourists, are motivated to varying degrees by both a desire to make a difference and a thirst for adventure" (Sichel 2006).

Sally Brown (2005) outlines a different reason: voluntourism is "considered to be very effective for 'corporate burnout,' because the individual gains a sense of accomplishment outside of the workplace" (Brown 2005). While Brown (2005) used a break from the workday grind as the largest motivation to voluntour, Sichel's (2006) adventure reasoning is not totally at a loss. It remains important to note that only those

\section{${ }^{2}$ Altruism tourists}


worthy, developed and living in the West suffer from 'corporate burnout'; ignored in this justification for voluntourism is the privilege in simply having a job to tire of.

Voluntourists, for better or worse are motivated by "opportunities to exchange information about networks and to form ties that might have not developed otherwise" (McGehee and Santos 2005). The voluntourists' motivations are widespread, complex and tend to contradict one another in coming from both a place of resume building and a self-appointed altruistic duty. Though the voluntourist lacks "an overtly political mission, voluntourist actions are impractically political in nature. Voluntourism, simply stated, is motived by a fluctuation between 'altruism and egoism"” (McLennan 2014). There is a desire to help along side a desire to say they helped and be seen helping.

As distinctions between motivations begin to arise, so to do the differences between motivations of voluntourism and tourism itself. While not addressed in this paper, it is important to note that voluntourism is vastly different from the vacation tourist, concerning the participant's motivation.

\section{MOTIVATIONS OF VOLUNTOURISM ORGANIZATIONS}

Because of the wide range of voluntouring opportunities, it is important to look at the differing and similar goals of many short-term voluntourist organizations. A quick Internet search provides an array of options for the aspiring voluntourist, outlined in the table below (“Cambodia" 2017; Noel 2017; Office 2017; User 2017; "Volunteer in Tanzania - Help Raise Children's Potential” 2015, “Conserving Endangered Rhinos in South Africa” 2017, “Cross-Cultural Solutions: This Changes Everything.” 2017, “HOME- Volunteer Abroad with United Planet | (Your Journey Here)” 2017). The similar monetary cost and stated goals of each voluntourist organization is telling. 
Regardless of the type of voluntouring or the location, the mission of 'helping' seems to hold true to every example.

\begin{tabular}{|c|c|c|c|}
\hline $\begin{array}{l}\text { Name of } \\
\text { organization }\end{array}$ & $\begin{array}{l}\text { Cost of } \\
10-20 \\
\text { day } \\
\text { trip* }\end{array}$ & Type of trip & Stated mission/goal \\
\hline Projects Abroad & $\$ 2,790$ & $\begin{array}{c}\text { Farming in } \\
\text { Argentina }\end{array}$ & $\begin{array}{l}\text { "A great way to give back to the } \\
\text { community while learning about organic } \\
\text { farming practices" }\end{array}$ \\
\hline $\begin{array}{l}\text { International } \\
\text { Medical Relief }\end{array}$ & $\$ 2,790$ & $\begin{array}{l}\text { Medical work in } \\
\text { Cambodia }\end{array}$ & $\begin{array}{l}\text { "Improve access to healthcare and } \\
\text { preventative education to health } \\
\text { condition }\end{array}$ \\
\hline United Planet & $\$ 3,495$ & $\begin{array}{l}\text { Teaching English in } \\
\text { China }\end{array}$ & $\begin{array}{l}\text { "Service, making a difference, building } \\
\text { a global community... Get outside your } \\
\text { bubble, jump into a real experience, } \\
\text { become a global citizen" }\end{array}$ \\
\hline Amizade & $\$ 2,950$ & $\begin{array}{l}\text { Community } \\
\text { development in } \\
\text { Jamaica }\end{array}$ & $\begin{array}{l}\text { "Helping with building projects, } \\
\text { developing parks, or working with local } \\
\text { children" }\end{array}$ \\
\hline $\begin{array}{l}\text { Cross-Culture } \\
\text { Solutions }\end{array}$ & $\$ 3,251$ & $\begin{array}{l}\text { Child Development } \\
\text { in Ghana }\end{array}$ & $\begin{array}{l}\text { "We can help break the cycle of } \\
\text { poverty... meet developmental goals, } \\
\text { supporting nutrition projects, health care } \\
\text { services, create a loving home } \\
\text { environment" }\end{array}$ \\
\hline EarthWatch & $\$ 3,575$ & $\begin{array}{l}\text { Rhino Conversation } \\
\text { in South Africa }\end{array}$ & $\begin{array}{c}\text { "Help researchers to study the impact of } \\
\text { rhinos on their environment and how it } \\
\text { could be affected by their } \\
\text { disappearance" }\end{array}$ \\
\hline $\begin{array}{l}\text { Global Aware } \\
\text { Adventures in } \\
\text { Service }\end{array}$ & $\$ 1,430$ & $\begin{array}{l}\text { Teaching English in } \\
\text { Vietnam }\end{array}$ & $\begin{array}{l}\text { "Teaching English pronunciation and } \\
\text { colloquialisms, the building of } \\
\text { playgrounds and better homes to replace } \\
\text { substandard housing" }\end{array}$ \\
\hline Global Volunteers & $\$ 2,095$ & $\begin{array}{l}\text { Teaching Africans } \\
\text { about health care }\end{array}$ & $\begin{array}{l}\text { "Your contribution to health, nutrition, } \\
\text { education and construction projects } \\
\text { helps parents provide Essential Services } \\
\text { to their children that prevent stunting } \\
\text { and allow children to realize their full } \\
\text { potential" }\end{array}$ \\
\hline
\end{tabular}

*airfare not included in prices 
This same state mission is somewhat lacking in the true motivations of voluntourists. A voluntourist might seek to build a CV or resume (Daldeniz and Hampton 2010; Wearing 2001); voluntourists also mentioned the pull of international adventure or a break from corporate burnout (McGehee and Santos 2005; Brown 2005). There is a sense these voluntourists want to 'help': traveling to far-away countries that are riddled with economic disparity. By choosing countries seen as culturally incomplete and still 'developing', the voluntourist seeks to pull their newly found hosts out of the slums gripping their lives. However, this clearly selfish but seemingly altruistic motivation, albeit skewed, pretentious and ignorant, is never listed as a top priority or motivation for a potential voluntourist partaking in and paying for a voluntourist trip.

The gap of motivations between the organizations delivering the opportunity to voluntour and those paying to help abroad is amassed and displayed in the following comparative table. Though the stated motivations of the voluntourism organization is to 'help' or 'develop' specific countries, these organizations exist in a capitalist market economy and their true goal must be to make a profit.

\begin{tabular}{|l|l|}
\hline \multicolumn{1}{|c|}{ Organization } & \multicolumn{1}{|c|}{ Voluntourist } \\
\hline $\begin{array}{l}\text { Give back to the community: } \\
\text { Projects Abroad, Global Volunteers }\end{array}$ & $\begin{array}{l}\text { Resume building } \\
\text { (Daldeniz and Hampton 2010, Wearing } \\
\text { 2001) }\end{array}$ \\
\hline $\begin{array}{l}\text { Improve local conditions through } \\
\text { development: } \\
\text { International Medical Relief, Amizade, Cross-Culture } \\
\text { Solutions, Global Aware Adventures in Service }\end{array}$ & $\begin{array}{l}\text { Self enhancement } \\
\text { (Daldeniz and Hampton 2010, } \\
\text { McLennan 2014) }\end{array}$ \\
\hline $\begin{array}{l}\text { Making a } \\
\text { difference: } \\
\text { United Planet, Global Volunteers }\end{array}$ & $\begin{array}{l}\text { Pursuing adventure } \\
\text { (Brown 2005) }\end{array}$ \\
\hline $\begin{array}{l}\text { Research: } \\
\text { Earth Watch }\end{array}$ & $\begin{array}{l}\text { Proliferation of ideas (McGehee } \\
\text { and Santos 2005, Wearing 2001) }\end{array}$ \\
\hline
\end{tabular}




\section{IMPACTS OF VOLUNTOURISM}

Voluntourism, because of its nuanced nature, can be challenging to box into any sort of framework or path. However, below, I outline both the positive and negative impacts of voluntourism, compiling data and previous research from all over the world.

\section{Positive}

Because voluntourism is growing rapidly as a form of abroad engagement, often the benefits of its practice seem to outweigh the costs, merely because its popularity. Outlined below are the often marketed and academically sound positive impacts of voluntourism. I was unable to find country specific proof of these positive impacts. Rather, all positive support of voluntourism came from the voluntourists, themselves. As we will see, the positive impacts do little to support the hypothesis that voluntourism produces positive outcomes for both sides of the voluntourism relationship. Because there is no research outlining the positive impacts for voluntourism through the eyes of the receiving country, clearly it would be easy to speculate that no positive impacts exist. This might well be true and deserves a separate research project.

Economic development of hosting country ${ }^{3}$

The implied purpose

of voluntourism is to help

those countries that are

considered 'developing'. The

Development status of a
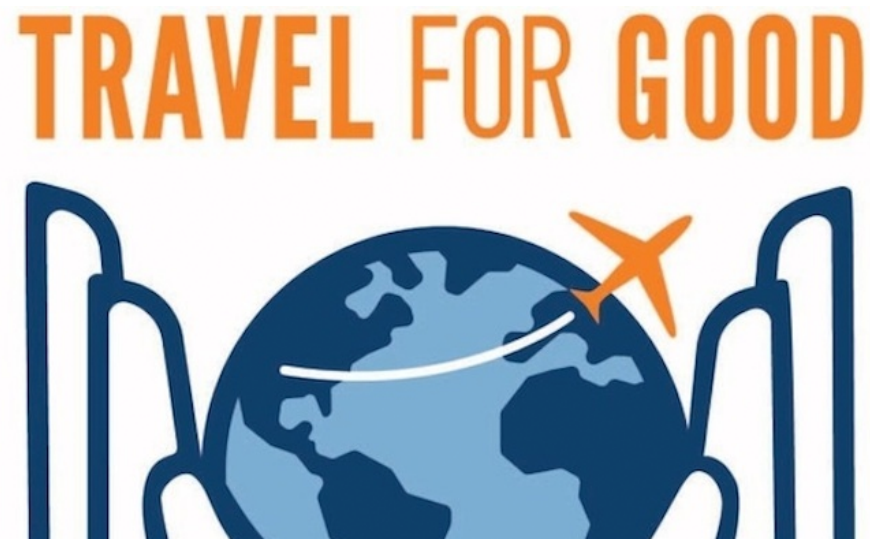

${ }^{3}$ Photo courtesy of Travelocity's 'Travel for the Good' Campaign launch

(“Travelocity Re-Launches Its ‘Travel For Good' Voluntourism Program” 2017) 
country is based on the United Nations analysis and index, using economic conditions, fuel exporting capacity, gross national income, human assets index, and the country's economic vulnerability in determining a country's position within a development category ("Country Classification: Data Sources, Country Classifications, and Aggregation Methodolody" 2014).

Nancy McGehee and Kathlee Andereck (2009) note that voluntourism has the potential to contribute immensely to the development of the hosting country; further, they state, voluntourism is "the ultimate form of sustainable tourism" (McGehee and Andereck 2009). Claire Dykhuis analyzes the positive impacts of voluntourism in 'Youth as Voluntourists: A Case Study of Youth Volunteering in Guatemala' (2010). She finds that voluntourism isn't inherently negative and has many positive impacts for both the participants and the hosts; the most important and prominent of which is providing projects intrinsic to the local hosting country's development.

\section{Increased global awareness and engagement}

Potential tourists deciding between volunteering and traditional vactioning are very much motivated, because of their desire to engage with different communities and 'help', as seen in the motivations section. This motivation contributes directly to the main positive impact of voluntourism: the human interaction and a deeper understanding of personal privilege on the side of the voluntourist.

Sally Brown (2005) notes that voluntourists tend to come home with a sense of fulfillment, that they added goodness to the world and that the volunteering aspect was the biggest highlight of their trip (Brown 2005). Brown (2005) outlines the positive benefits of voluntouring through the eyes of the tourist: "...The helping and giving 
efforts appeared to provide a window for international communities to understand the American people, projecting a friendly, generous, and one informant attested helpful American image".

Many voluntourists felt that had left a lasting impact, "permeated beyond the vacation trip itself" (Brown 2005). The enduring impacts seem to be more focused around the social interactions gained from the voluntourism experience- not necessarily the project itself. Brown (2005) addresses only the benefits of voluntourism from the viewpoint of the voluntourist. This is a large gap in her research and begs the question: what is the benefit of voluntourism for the country being voluntoured in? ${ }^{4}$ In her article considering specifically medical voluntourism projects, McLennan (2014) studies voluntourism in Honduras,

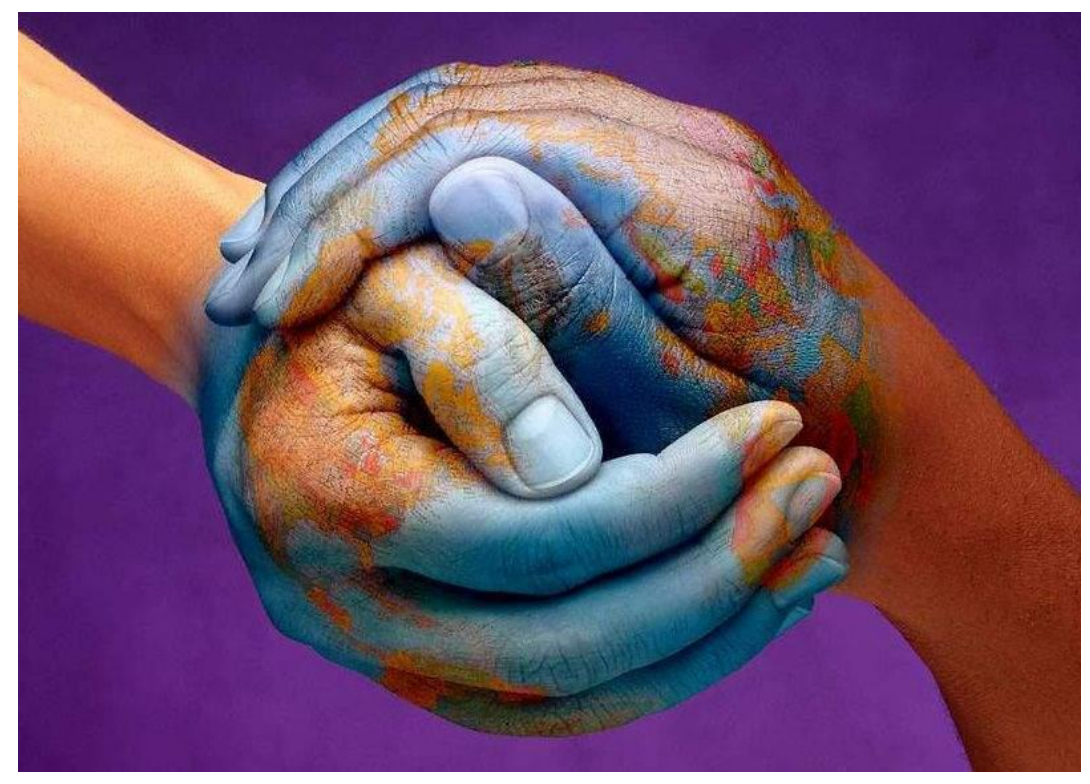
suggesting recently returned voluntourists have "aspirations of goodness", that voluntourism offers a "realistic but creative and empowering way of mobilizing people globally for development" and that voluntourism ultimately has the potential to "shape new thinking and help 'humanize' globalization” (McLennan 2014). Voluntourism presents a "unique opportunity" to engage and be exposed to "social inequalities as well

\footnotetext{
4 Photo Courtesy of Google Images via 'Master of Something' Blog (Yet 2015)
} 
as environmental and political issues" and that this engagement will "subsequently lead to increasing social awareness" (McLennan 2014). These positives benefits, once again, look only at the voluntourists experience and ignore any sort of conversation of benefit or cost for the receiving country and it's locals.

McIntosh and Zahra (2009) mention three tiers of meaningful takeaways the voluntourist carries, including a deeper understanding of a different culture, an increase of self-awareness and a "creative cultural exchange", of ideas and narratives between the host country and the voluntourists. Voluntouring, they conclude, is a viable alternative to the more normal forms of tourism and is "beneficial to both host and volunteer... based on meaningful interaction" (McIntosh and Zahra 2007).

The clear and commonly held is the view that, "...there is great potential for both hosts and volunteers to walk away from a volunteer tourism experience with a better understanding of each other” (McGehee and Andereck 2009). This interaction can, apparently, only help to better our understanding of one another and our acceptance of difference, therefore bettering the world. Voluntourism, in the eyes of its endorsers, is therefore more beneficial than it is costly.

Ignored almost entirely in the literature seeking to assess the positivity of voluntourism, are the impacts on the host communities. There might be brief mentions of the benefits of human interaction for the host country to meet a 'Westerner'; and there is much written on the supposed economic benefits of voluntourism. However, “...The lack of academic attention to the perspectives of host communities is telling of the assumptions that surround volunteer tourism; the host community is irrelevant in the equation of 'development' that is simply, generously, and neutrally bestowed upon it by 
Western volunteers" (Pastran 2014). The understanding that development, economic or otherwise, will immediately lead to a 'betterness' in inherently colonial and ignorant to the complex effects 'aid' or help of any sort, can create. Outlined below are the negative impacts of voluntourism and their relationship to host countries all over the globe, through case-study examples. The positive impacts for the host country is assumed rather than tested and explained. The explicit positive impacts gained through voluntourism is never questioned, only presupposed.

\section{Negatives}

There are many negative impacts of voluntourism. Examining voluntourism beyond a surface level analysis as well as addressing how voluntourism affects the receiving country reveals the modern colonial outcomes voluntourism often leaves behind. Argued by Marc Epprechet (2004), is the need to address a common assumption in international and tourism studies: that development-themed work-study abroad programs are "so intrinsically valuable" that their benefits must outweigh any possible adverse effects". This assumption ignores the larger nuanced issues development work like voluntourism leaves behind.

Outlined below are the negative costs and impacts voluntourism can and does leave behind; the negative impacts of voluntourism are best seen in application and practice through case-study analysis of a hosting country. Each impact has a correlated country or countries showing it's real-world applicability and the harm the impact has created or enhanced. 


\section{Advancement of Neocolonial Relationships}

Before examining the neocolonial impacts, we must define the term. Neocolonial is "the economic and political policies by which a great power indirectly maintains or extends its influence over other areas or people" (Merriam-Webster). Neocolonialism has come to be thought of and understood as a modern manifestation of the colonizing of the 'Third World'. Neocolonial isn't necessarily physical intrusion into a country or gaining governmental control through force or coup. Rather, neocolonialism is more intricate and discrete in its purpose and impact. Voluntourism presents an interesting question when asking if it advances neocolonial relationships built on power dynamics based on wealth and color of skin.

Sasha Pastran (2014) analyzes the post-colonial impacts of voluntourism, stating that voluntourism "does little more than reinforce unequal power relationships and cultural stereotypes between tourists and hosts" and is therefore neocolonial in nature (Pastran 2014). Voluntourism is perpetuating a colonial relationship by "continuing impacts on the political, economic, and social development of both the former colonizer and colonized" (Pastran 2014). Brown (2005) argues that this interaction is what makes the voluntourism experience so powerful and long-lasting for the tourist; Pastran (2014) disagrees: it's this relationship, the one who is giving [delivering] and the one who is receiving, that perpetuates these costly notions of first and third world, of developed and developing countries. "By its nature, volunteer tourism brings together economically powerful volunteer tourists (who have enough discretionary economic resources to be able to afford a trip to volunteer abroad) with less powerful host communities (who are deemed "poor enough" to place them in the position of being 'voluntoured'). This 
drastically unequal relationship cannot be ameliorated in the short time frame that most voluntourism ventures last" (Pastran 2014). The power dynamic naturally created through voluntourist action is dangerous and costly.

Epprechet (2004) argues that "unequal relationships" are built and structured into society and are profound, even subconscious levels. Those relationships are particularly worrisome when considering sending privileged students to work in the developing world. ${ }^{5}$ The voluntourist is not required to have any prior experience of international aid or any understanding of the receiving country's possibly colonized history. This gap in education further divides the economically powerful receiving country from the economically disadvantaged and developing receiving country.

Hidden from the conversation of the positive impacts of voluntourism is the

"complex
relationships
between the
tourists and
toured"
(Pastran
2014). These
impacts, while

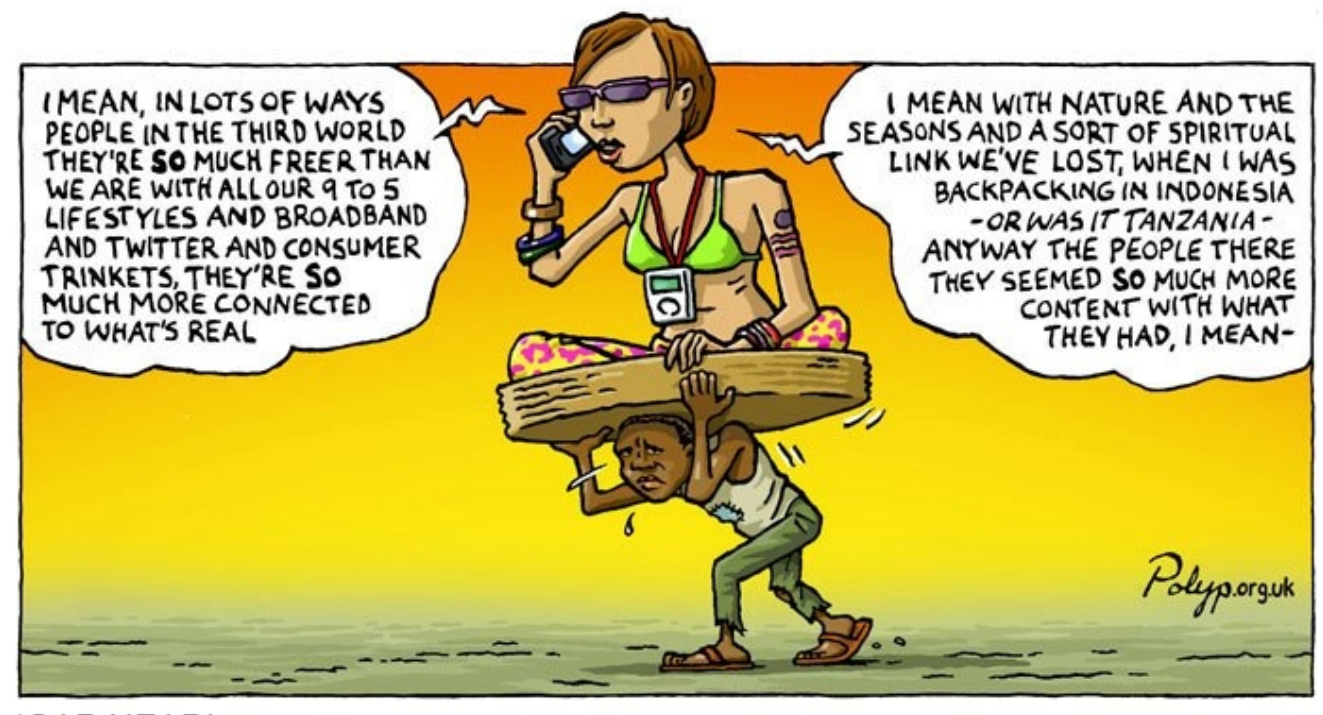

'GAP HEAD'

not inherently based in economics, have development implications for the country being voluntoured in: a continued legacy of colonialism already exists without the complication of voluntourism (loans from IMF etc.). Voluntourism adds the complexity of social

5 Photo courtesy of Polyp Comics (“Polyp: Political Cartoonist: Home Page” 2017) 
expectations, issues of reliance on voluntourist organizations and unhealthy powerdynamic relationships.

McLennan (2014), addressing the potential negative concerns of voluntourism, mentions that voluntourism may actually reinforce "stereotypes and actively [promote] an image of 'Third World other' that is dominated by an 'us and then' mind-set" (McLennan 2014). Daniel Guttentag (2009) and Kate Simpson (2009 support the idea that stereotypes are reinforced through the practice of voluntourism: locals are seen as poor but happy. This attitude allows "material inequity to be excused" and justified, leading to a romantization of poverty and an association of poverty with social and emotional wealth (Guttentag 2009; Simpson 2004). The dysfunctional understanding of poverty does nothing to reduce or change the systematic inequality most receiving countries seek to overcome. Rather, the neocolonial tendencies of voluntourism expand the West's system of suppression and the idea of 'manifest destiny'.

\section{Neocolonial relationships in}

\section{Honduras, Guatemala, Thailand}

Using Honduras as a case study, McLennan (2014) studied medical voluntourism through qualitative analysis, noting that voluntourism fails, regardless of the project left behind, if the "neo- colonialist and dependency-producing pattern... entrench [the] inequitable relationships... which may undermine the skills, resources and knowledge of Hondurans" (McLennan 2014). The inequitable relationship that tends to develop between the Honduran and the voluntourist is tricky; indeed, McLennan argues, 'help' itself is tricky: "this process of helping a particular section of society or humanity to 'catch-up' is not really development, but is a manifestation of paternalism” (McLennan 
2014).

In following a voluntourist trip to Guatemala, Dykhuis (2010) followed a group of high school students to Nicaragua during their voluntourism experience. The study argues that if voluntourism is to be successful in the future, education must be a preliminary component. This seemed to be lacking in the participants she observed: “... the students were poorly equipped both for developing awareness about the stereotypes to which they seemed to describe and for gaining a deeper understandings of the global inequalities that voluntourism programs ostensibly seek to redress" (Dykhuis 2010). Clearly, a lack of prior understanding or a post-trip-briefing concerning the impacts of the volunteer work just completed leaves voluntourists with a feeling of elevation and 'betterness' attributed to the work they just completed while leaving a large gap in the conversation concerning their privilege.

Conran (2011) studied voluntourists in Thailand through extensive country-based research and partnerships with nonprofits in Thailand. Conran (2011) concludes with a common thought in the voluntourist community: there is an "implicit assumption in volunteer tourism that some lives are for saving while others are for being saviors" (Conran 2011). Interestingly, Thailand is not a post-colonial nation: Thailand has never been colonized. How, then, can Thailand's voluntourism industry perpetuate colonial tendencies? Again, unignorable is the inherent relationship of 'the west versus the rest' (Huntington 1993).

There is an obvious gap between those who have the ability to voluntour and those who are 'helped' by a voluntourist: “...Aspects of volunteer tourism are 
reminiscent of this historical relationship between Thailand and 'developed' countries, where Euro-American capitalist modernity is aggrandized and unequal power relations are perpetuated" (Conran 2011). The relationship of the voluntourist to the local does not necessarily have to be directly correlated to a historic relationship of colonizer and colonized; it can be, more clearly and concurrently, a relationship built on an 'us versus them' mentality.

\section{Lasting economic development and aid reliance}

Does voluntourism produce economic dependency by cultivating reliant relationships? "A host community may become dependent on volunteers when these [projects] are promoted at the expense of longer term or community driven initiatives" (McLennan 2014). Short-term projects have the potential to leave behind a need for yet another voluntourism group to come in and 'save the day'. Does this cycle actually promote successful development within the receiving country or simply add another complexity to the aid versus trade discussion? This question is not within the scope of this thesis but it does prove important to the conversation of long-lasting impacts of voluntourism.

One of the most totted benefits of voluntourism is the potential for increased or faster economic development. However, if voluntourism is creating a relationship built on dependency, this benefit is fallacious: “...just because a community is hosting a volunteer tourism project, one should not assume that the community will inevitably benefit economically" (Guttentag 2009). 


\section{Economic concerns and aid reliance in}

\section{Honduras and Thailand}

In examining Honduras, McLennan (2014) notes that the sometimes volatile and dynamic nature of 'developing' countries usually chosen for voluntourism projects is risky and potentially harmful- not to the voluntourist, themselves, but to the country: "As a form of aid... it is subject is changes in the global economy and tourist industry". She notes that over the course of three years, the number voluntourists in Honduras fell rapidly after the 2009 coup and then again in 2012. At this time, however, Honduras and her economy had already come to rely of voluntourists and the resources they bring. Voluntourism is not alone to blame for an economic crisis or political uprising; however, voluntourism must be examined through a larger lens than merely its initial impact: if countries continue to rely on voluntourism projects to build new schools, functioning water wells and even provide medical care to locals, voluntourism cannot act in reaction to the political economy of the country- it must exist in the face of these problems if it is to be a major component of a functioning economy in a developing country.

In Thailand, Conran (2011) explains that $70 \%$ of the tourism economy experiences "profit leakage" due to foreign control, meaning that, even though Thailand's economy is almost entirely reliant of tourism (and, therefore, voluntourism) much profit is ultimately lost. This is due, in large part, because the voluntourism sector is almost entirely controlled by foreign countries. Voluntourism organization arebased in the delivering country rather than the receiving country are unable to make as great a potential profit because of the costs involved in international relationships (Conran 2011). This creates a dependency cycle where, even if tourism and voluntourism creates and 
stimulates the economy, that stimulation links directly to foreign powers and their economic success rather than the success of the receiving country.

\section{$\underline{\text { Emotional cost of short-term voluntourism trips }}^{6}$}

Beyond the economic and social dynamic between voluntourist and local, the outright "emotional costs of attending to the constant stream of visitors can lead to... community burnout” (Epprecht 2004). Benjamin Sichel (2006) analyzed that “...many altourists [voluntourists] may be remarkably uninformed about the true reasons behind economic disparities between North and South" leaving the locals to either explain to the voluntourist the true impact of their work or leave the voluntourist in a state of ignorancean exhausting choice.

This paper defines voluntourism through a short-term lens: less than three month spent voluntouring. Clearly, the short-term nature of these projects often leaves behind unfinished work and resources wasted: "Short-term 'fixes' might be offered and in fact benefit individual recipients, but overall the community would benefit more from other types of assistance, such as education of local health care personnel" (McCall and Iltis

2014).

Daldeniz

and Hampton

(2010) note the

emergence of a

tension based on

cultural ignorance

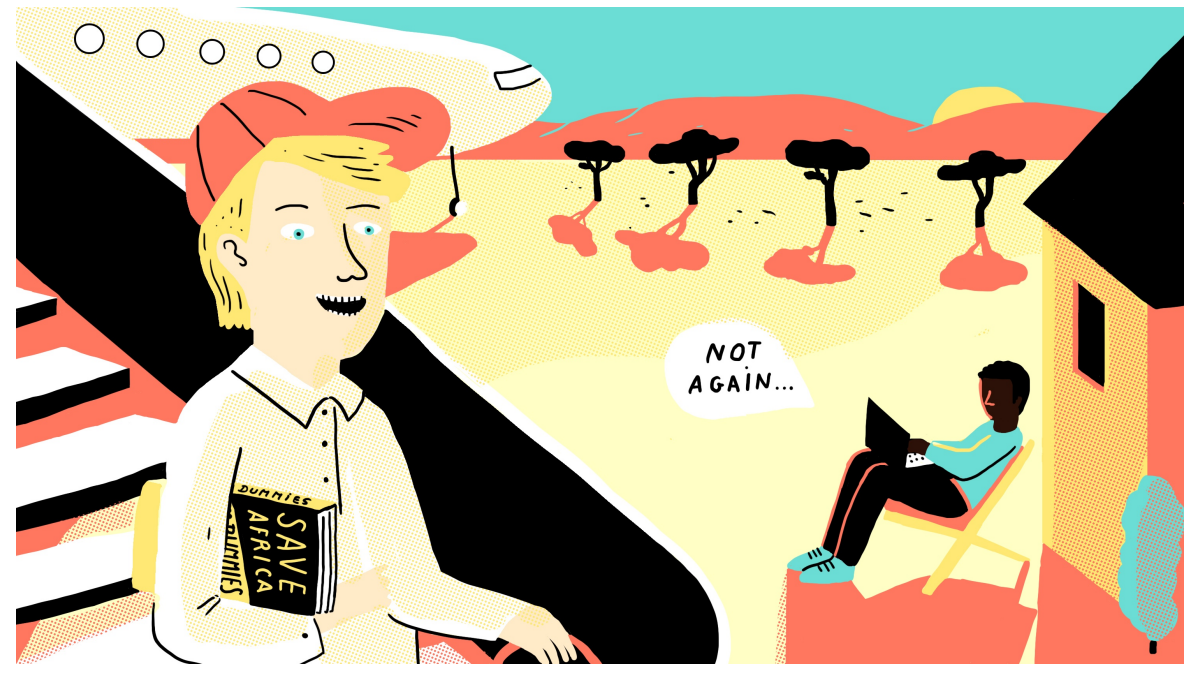

6 Photo courtesy of Polyp Comics (“Polyp: Political Cartoonist: Home Page” 2017). 
between the voluntourist and the host. This cultural ignorance influences not only the budding neocolonial relationship but also the communication and conversation held between the voluntourist and the local. A lack of cultural awareness on the part of the voluntourist could lead to dangerous misunderstandings of culture and rude ineptitude.

\section{Emotional cost and impact of time/length of project in Honduras, Malaysia}

There is an emotional cost for the host country is the continual lack of education of the voluntourists. Often, there is little to no language shared, little understanding of the host country's history and further still, "few organizations involved in medical voluntourism in Honduras offer formal education and consciousness-raising activities for participants" (McLennan 2014).

An emotional cost is left through the process of "“emotional capitalism', where the practice of 'doing good' becomes consumable, through blending of the intimate and the emotional with economic discourse" (Mustaffa 2015). Mustaffa (2015) studied the impacts of voluntourism in Malaysia and found that this commodification of altruism leaves countries feeling used and exploited: "Rather than focusing on ways to assist in improving quality of livelihood, the impoverished attributes of a place and its inhabitants are fetishized as 'the exotic other' - a distinctiveness that has become yet another commodity for tourists to adorn themselves with" (Mustaffa 2015). The commodification of the poor is at the emotional expense of the receiving country. The country is left with unfinished development projects and unfinished relationships built on ignorance. 


\section{Environmental Impacts and Resource Management}

Often ignored in the discussion of tourism and therefore voluntourism is the environmental impact of the tourists' actions: "By its nature... tourism is... highly wasteful of resources financially and environmentally" (Epprecht 2004). The environmental impacts of large tourist buses gallivanting up and down a country's coastline is unaccounted for in the voluntourism costs. The idea of "wasted resources", that is, the constant and continual stream of foreigners who promise to leave their "positive and lasting impact" (Brown 2005) actually leave a ten-day long unfinished project that the local community has neither the time nor resources to finish. These unfinished projects leave a constant reminder of the 'western touch' and a pile of wasted sources that could've been used at the community's discretion.

Because voluntourist organizations often promote projects based on the interests of only the organization, "host communities often have only limited power in influencing when volunteers can come, where they will go and what they will do" (McLennan 2014). This is exhausting to host communities that might desperately need a water well but end up with another community play-ground because of the desires of the voluntourists and their travel organization. “...In its current structure, voluntourism doesn't address real need, with tourists shaping it to what they want" (Patel, 2013).

Further, voluntourist projects often take jobs away from locals who could've applied or worked instead (Daldeniz and Hampton 2010). In much of the developing world, consistent work is hard to find. If an organization has the means to build a school, why not finance and pay locals to construct it? Wasted energy is still a wasted resource. 


\section{Environmental/wasted resources in}

Haiti

Using 2010 post-earth quake Haiti an example, McCall and Iltis (2014) study undergraduate medical voluntourism trips and note that because a large number of voluntourists wanted to dispense 'their' aid on the ground, basic supplies like water and fuel were incredibly short supply being provided to the voluntourist instead of the local community. Examining the international reaction to the 2010 earth quake in Haiti, McCall and Iltis (2014) found that, because of their balancing motivations of altruism and personal gain, voluntourists were more concerned with being on the groun and in the action, than actually helping to build and repair. Because of this, "basic supplies, such as clean water and fuel, were in very short supply and there were significant delays in providing assistance to those whom they wanted to help" (McCall and Iltis 2014). Voluntourists were almost literally taking the food out of the mouths of locals because of their desire to not just help, but be seen helping. These resources, crucial to the rehabilitation of post-earth quake Haiti, were necessary to both the repair of the country and the health of the locals. The resources were indeed wasted on mouths of those who could've just sent the money they spent on airfare instead of flying across the global to been perceived as altruistic. 


\section{AN END TO MEET ITS CONSEQUENCES: ULTIMATE WESTERNIZATION ${ }^{7}$}

An accumulation of the impacts listed above clearly lead to the Westernization of the world. Westernization to this extent occurs because of the social relationships, environmental concerns and economic outcomes of voluntourism. Is voluntourism simply imposing the 'right-way to develop' mantra onto these voluntourism countries? “...We can easily appreciate that it was historically a central goal of international exchange: to

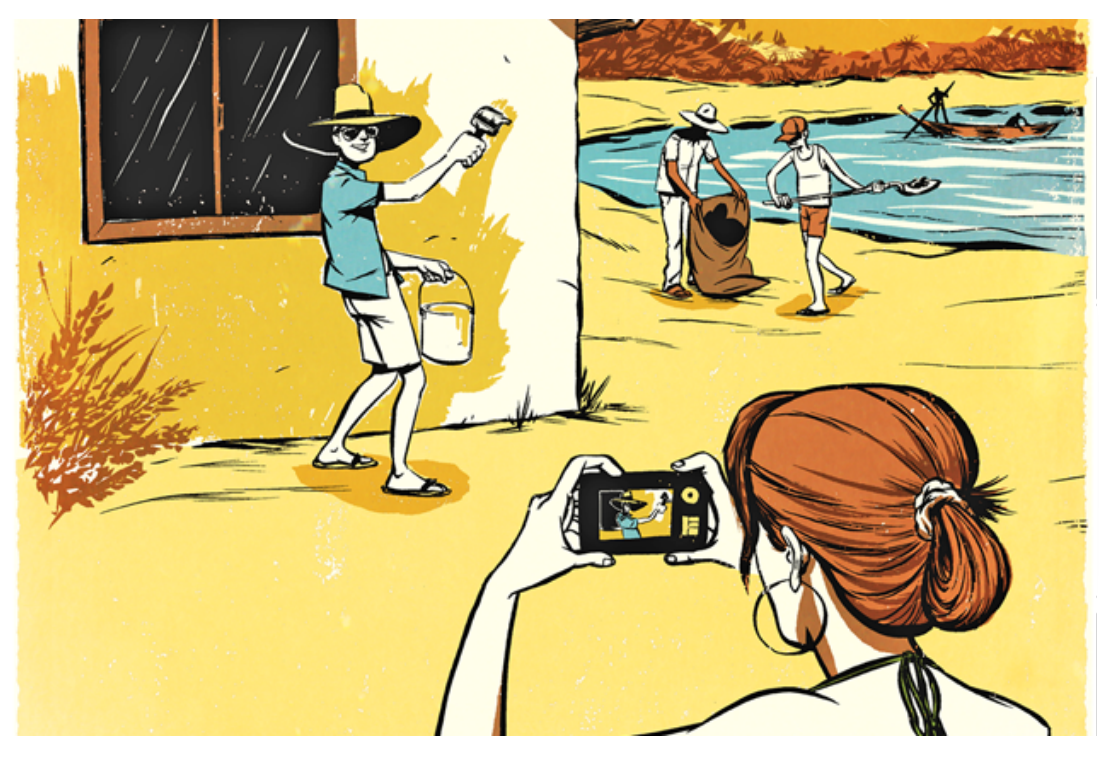
convert Them (natives, foreigners, etc.) to be more like Us (Christians, Free World)" (Epprecht, 2004). This dichotomy is seen not only from the examples of countries analyzed above, but all over the world.

Beyond the scope of this paper but critical to the subject matter and continued conversation is the question of westernization: is it good or bad? Without answering this question, conclusion surrounding voluntourism, clearly a piece of the Westernization process, can only be presumed and not assured.

${ }^{7}$ Photo courtesy of Conde Nast Traveler (Elliott 2017). 


\section{CONCLUSION}

Much of the discourse community agrees: voluntourism isn't inherently negative and it definitely isn't entirely positive. Many authors encourage the voluntourist sector to recreate itself and build models based on a community's needs rather than imposing ideas of right and wrong. Natalie Jesionka (2014) states:

While we do need to note the critiques of the volunteer and social good industry and increase awareness of how they operate, we should also talk about the complexity of the volunteer sector, instead of only placing the blame on volunteers. We need to examine the entire system of "doing good," not just condemn individuals. By having a broader discussion about the systems behind the critiques, we can help create more effective and impactful volunteer and travel opportunities in the long run.

Jesionka (2014) also states "voluntourism is not only a Western problem". While the author lists many missteps of voluntouring and voluntourists, she believes the solution lies in the conversation: "Maybe it's time for volunteers to stay aware and informed about all facets of the debate... That's just it: We need to start being honest about why we travel and why we volunteer" (Jesionka 2014).

This paper's results are both clear and inconclusive: voluntourism is merely a modern form of colonialism (neocolonialism). Voluntourism is more detrimental that beneficial to the receiving country, both economically and socially. This conclusion is widely supported: voluntourism is "yet another form of post-colonialism and globalization, evidenced by exploitative tourism that occurs in many developing regions of the world" (McGehee and Santos, 2005).

Voluntourism isn't inherently or intrinsically negative. Credit must be given to the NGO's and governmental agencies that are indeed helping countries (Epprecht 2004). 
Many organizations work tirelessly to address community requests and needs, highly vet their volunteers and encourage the prior education of the history of development abroad.

Yet still, there are far too many organizations in operation that are "corrupt, ineffective, and/or downright harmful to development, often in ways that are fatally obscure to partners unfamiliar with the local context" (Epprecht 2004). We must remember, "there is room for faults" (Dykhuis, 2010). International interaction will never be perfect or without reason to question or critique. Further, "voluntourism is almost impossible to generalize because of the wide range of experiences and research" (Dykhuis, 2010). Voluntourism is broad and far reaching- it's a world affair and defining a script or practice for all organizations alike would be difficult. However, its worth discussing further, beyond this paper.

More importantly is the discussion of voluntourism implications, both negative and positive and meeting organizations where they are at: “...voluntourism organizers need to truly acknowledge the intricacy of making the experience positive and successful, and only then it can certainly be beneficial" (Patel 2013). A continued conversation with the voluntourist can only lead to a better understanding of its true purpose and a more transparent recognition of the potential sacrifices and gains of voluntourism. Also needed is conversation with the receiving country, addressing the community's stated needs. Voluntourism organizations need to acknowledge their part played in the capitalist structured world and their desire for profit in our market economy. This fact remains unexplored yet unignorable in today's discussion of voluntourism, both motivations and impacts. 
In conclusion, voluntourism, while not malicious in intent, is clearly, in current practice, neocolonial in nature. The negatives of voluntourism, listed above, outweigh the short list of potential positives. Cross-cultural engagement, noted as a large motivation and positive outcome of voluntourism, has many other arenas to grow and thrive, without broadening the 'us versus them' relationship voluntourism creates. The negatives of voluntourism are long and winding; they are too often ignored and not easily prevented.

This conclusion leaves the voluntourist industry with questions on how to continue. To that I respond: a complete examination of practices, mission statements and better vetting of voluntourists is needed before such projects can truly be said to more positively impact a receiving country than negatively. A pre-trip conversation of the receiving country's history and the power dynamics at play in a 'help-based' relationship should be a required prerequisite of all voluntourism trips. A post-trip debrief should help the voluntourist to understand their feelings and evaluate the impact of their trip, both negative and positive.

Voluntourism is here to say. It's a small yet growing industry helping to weaken borders and globalized the world. Voluntourism is a piece to the development puzzle, undeniable the more we travel and explore internationally. The nuances of voluntourism impacts must be addressed, as seen in this paper, before voluntourism can be said to have a lasting and positive legacy. 


\section{REFERENCES}

Beigbeder, Yves. 1991. The Role and Statuts of International Humanitarian Volunteers and Organizations: The Right and Duty to Humanitarian Assistance. Martinus Nijhoff Publishers.

Brown, Sally A. 2005. "Voluntourism---Traveling with a Purpose: Understanding the Motives and Benefits.” Theses and Dissertations Available from ProQuest, January, $1-125$.

“Cambodia.” 2017. International Medical \& Dental Relief. Accessed May 17. http://www.internationalmedicalrelief.org/medical-missions/cambodia/.

Conran, Mary. 2011. “They Really Love Me!: Intimacy in Volunteer Tourism.” Annals of Tourism Research 38 (4): 1454-73.

"Conserving Endangered Rhinos in South Africa." 2017. Accessed May 17. http://earthwatch.org/Expeditions/Conserving-Endangered-Rhinos-in-SouthAfrica.

"Country Classification: Data Sources, Country Classifications, and Aggregation Methodolody.” 2014. United Nations. http://www.un.org/en/development/desa/policy/wesp/wesp_current/2014wesp_co untry_classification.pdf.

“Cross-Cultural Solutions: This Changes Everything.” 2017. Cross-Cultural Solutions. Accessed May 17. https://www.crossculturalsolutions.org/destinations/volunteerghana. 
Daldeniz, Bilge, and Mark Hampton. 2010. "Charity-Based Voluntourism versus 'Lifestyle' Voluntourism: Evidence from Nicaragua and Malaysia.” Kent Business School No. 211 (May).

Dykhuis, Claire. 2010. Youth As Voluntourists: A Case Study of Youth Volunteering in Guatemala. Lulu.com.

Elliott, Dorinda. 2017. "Giving Back: A Special Report on Volunteer Vacations.” CNT. Accessed May 17. http://www.cntraveler.com/stories/2013-01-15/volunteervacations-rewards-risks.

Epprecht, Marc. 2004. "Work-Study Abroad Courses in International Development Studies: Some Ethical and Pedagogical Issues." Canadian Journal of Development Studies / Revue Canadienne D'études Du Développement 25 (4): 687-706.

Gillette., Aurther. 1968. “One Million Volunteers.” In . Penguine. http://www.ourstory.info/library/5-AFSIS/Gillette/volunteers01.html.

Guttentag, Daniel A. 2009. "The Possible Negative Impacts of Volunteer Tourism." International Journal of Tourism Research 11 (6): 537-51.

“HOME- Volunteer Abroad with United Planet | (Your Journey Here).” 2017. Volunteer Abroad with United Planet | (Your Journey Here). Accessed May 17. http://www.unitedplanet.org/.

Huntington, Samuel P. 1993. “The Clash of Civilizations?” Foreign Affairs 72 (3): $22-$ 49.

Jesionka, Natalie. 2014. "The Reality of Voluntourism and the Conversations We're Not Having." The Muse. April 29. https://www.themuse.com/advice/the-reality-ofvoluntourism-and-the-conversations-were-not-having. 
McCall, Daniel, and Ana S. Iltis. 2014. "Health Care Voluntourism: Addressing Ethical Concerns of Undergraduate Student Participation in Global Health Volunteer Work." HEC Forum 26 (4): 285-97.

McGehee, Nancy Gard, and Kathleen Andereck. 2009. "Volunteer Tourism and the 'voluntoured': The Case of Tijuana, Mexico.” Journal of Sustainable Tourism 17 (1): 39-51.

McGehee, Nancy Gard, and Carla Almeida Santos. 2005. "Social Change, Discourse and Volunteer Tourism.” Annals of Tourism Research 32 (3): 760-79.

McIntosh, Alison J., and Anne Zahra. 2007. “A Cultural Encounter through Volunteer Tourism: Towards the Ideals of Sustainable Tourism?” Journal of Sustainable Tourism 15 (5): 541-56.

McLennan, Sharon. 2014. "Medical Voluntourism in Honduras: 'Helping' the Poor?" Progress in Development Studies 14 (2): 163-79.

Mustaffa, Siti. 2015. "Voluntourism in Malaysia: A Study of Intimacy in the 'Do-Good' Industry.” Macquarie University.

Noel, Sara. 2017. "Volunteer Abroad Jamaica Spring Break | Amizade Fair Trade Learning." Amizade. Accessed May 17. https://amizade.org.

Office, Projects Abroad Inc, IT. 2017. "Volunteer Farming Project in Argentina | Projects Abroad.” Accessed May 17. http://www.projects-abroad.org/volunteerdestinations/volunteer-argentina/agriculture-and-farming/farming/.

Pastran, Sasha Hanson. 2014. "Volunteer Tourism: A Postcolonial Approach.” USURJ: University of Saskatchewan Undergraduate Research Journal 1 (1). 
Patel, Jigna. 2013. "Voluntourism: Once Invisible, Now Transparent." Tourism Students' Virtual Conference, Wolverhampton. http://www.travelconference.co.uk/commentries.php?paper=214\#.WHwaxLYrLUo.

“Polyp: Political Cartoonist: Home Page.” 2017. Accessed May 17. http://polyp.org.uk/. Sichel, Benjamin. 2006. "I've Come to Help: Can Tourism and Altruism Mix?" BriarPatch, November.

Simpson, Kate. 2004. “'Doing Development”: The Gap Year, Volunteer-Tourists and a Popular Practice of Development.” Journal of International Development 16 (5): 681-92.

“Statistics \& Facts.” 2017. Global Wellness Institute. Accessed May 17. https://www.globalwellnessinstitute.org/press-room/statistics-and-facts/.

“The Founding Moment.” 2017. Accessed May 3. https://www.peacecorps.gov/about/history/founding-moment/.

“Travelocity Re-Launches Its ‘Travel For Good’ Voluntourism Program.” 2017. Infinite Legroom. Accessed May 17. http://infinitelegroom.com/2015/09/29/travelocityre-launches-its-travel-for-good-voluntourism-program/.

User, Super. 2017. "Vietnam.” Accessed May 17. https:/globeaware.org/destinations/asia/vietnam.

Verardi, Cassandra. 2013. "Perceptions of Voluntourism.” Heritage Branch. https://curve.carleton.ca/system/files/etd/9555f4e4-156e-471a-a60bb8267f599005/etd_pdf/37fac09309ec38cf36a562712b9ff7a1/verardiperceptionsofvoluntourism.pdf. 
“Volunteer in Tanzania - Help Raise Children’s Potential.” 2015. Global Volunteers. October 28. https://globalvolunteers.org/tanzania/. volunteertourismviews. 2013. "Some History on Volunteer Tourism." VolunteerTourismViews. March 10. https://volunteertourismviews.wordpress.com/2013/03/10/some-history-onvolunteer-tourism/.

Wearing, S. 2001. Volunteer Tourism: Experiences That Make a Difference. CAB International.

Yet, Master of Something. 2015. "Voluntourism - Helpful Aid Or Just A Warm Fuzzie?" Master of Something I'm Yet To Discover. August 10. https://masterofsomethingyet.com/2015/08/10/voluntourism/. 